\title{
Cultural Acculturation Values in The Minaret of Kudus to Foster Harmony Through Social Studies Education
}

\author{
R. Suharso ${ }^{1}$, Wasino ${ }^{2}$, Dewi Liesnoor Setyowati ${ }^{3}$, Cahyo Budi Utomo ${ }^{4}$ \\ \{r.suharso@mail.unnes.a.ic ${ }^{1}$, wasino@mail.unnes.ac.id, liesnoor2015@mail.unnes.ac.id ${ }^{3}$, \\ cahyo.bu@mail.unnes.ac.id $\left.{ }^{4}\right\}$
}

Graduate School Universitas Negeri Semarang, Kelud Utara III Street of Semarang, Indonesia

\begin{abstract}
The rise of intolerant practices in society is in spotlight of Indonesian education today. This study aims to portrait social studies education in growing habitus tolerance. The research question is 1) what is acculturation of culture in Minaret of Kudus? and 2) how student tolerance can grow through social studies learning based on value of cultural acculturation in Minaret of Kudus. This research method is qualitative with case study design. This study involved 4 social studies teachers and 30 students. Findings of this study indicate that cultural acculturation in Minaret of Kudus building is very relevant to be taught in social studies learning, besides that Kudus Minaret has the potential to foster student tolerance habitus because the historical background of Kudus Minaret comes from a combination of Islamic-Javanese-Hindu culture. Implication of this study is social studies learning must be more contributive in responding to social problems in society.
\end{abstract}

Keywords: Acculturation Value, Kudus Minaret, Social Studies Education.

\section{Introduction}

Social studies education practitioners and academics in Indonesia are trying hard to provide learning that is able to respond to the practice of intolerance in society [1]. From year to year the number of cases of intolerance is increasingly alarming. Data from the Coordinator of the Desk on Freedom of Religion and Belief (KBB) of the Republic of Indonesia's National Human Rights Commission shows that the number of intolerance cases in 2016 continued to increase compared to the previous two years. The increasing trend in cases of intolerance concerns Indonesia's diversity. In 2014, National Human Rights Commission noted that 74 cases of intolerance were reported. In 2015, the number of complaints increased, which was 87 cases. In 2016 nearly 100 cases of intolerance occurred.

The case above underlies social studies learning that is oriented towards harmony of mankind [2]-[4]. Referring to Barr, Social Studies Education is one of the most progressive subjects to solve the problem of intolerance and war [5]. So far, the issue of citizens' rights and multiculturalism has become the root of each of these problems [6]-[8]. Banks revealed, in a multicultural society, the value of cultural acculturation is an important source to teach the importance of harmony [9]. In the Indonesian context, this value can be found in the Kudus Minaret, an ancient building that is very monumental for Nusantara civilization. The building is a symbol of religious harmony and tolerance because it is able to integrate 3 cultures at once, 
namely Java, Hinduism and Islam. According to Salam, this is a social capital to formulate a society that is peaceful and has the love of fellow religious people [10] [11].

This study aims to uncover, acculturation of culture in Kudus Minaret as a source of social studies learning. The focus of this study is on strengthening community harmony through social studies learning with cultural acculturation. The research question is 1) what is the acculturation of culture in the Minaret of Kudus? And 2) how can student tolerance grow through social studies learning based on the value of cultural acculturation in the Minaret of Kudus?

\section{Methods}

This is a qualitative project with a grounded theory framework [12]. The research method is used to see the extent to which social studies learning is able to strengthen harmony between students. This study focuses on three aspects that are commonly found in the process of forming citizens in social studies, namely the value of acculturation, education, and harmony. This study involved 4 social studies teachers in junior high school and 30 students. Through coding, I managed to get 7 pieces of data encoded through Student Number 1 (SN1), Student Number 2 (SN2), SN3, SN4, SN5, SN6, and 1 data from the teacher who was coded Teacher Number 1 (TN1). Both students and teachers come from different social backgrounds. In addition, the diverse religious domains also make the data obtained more varied. The data analysis used in this study is an interactive data analysis model.

Table 1. Social Studies Education Plan to Foster Harmony.

\begin{tabular}{cll}
\hline Time (Minutes) & Activities & Media of Teaching \\
\hline 5 & Opening & \\
15 & Submission of learning aims and activities & \\
20 & Show documentary film & Film of Kudus Minaret History \\
35 & Presentation and Discussion & Articles and Text Book \\
10 & Conclusions and Reflections & \\
5 & Closing & \\
\hline
\end{tabular}

The learning plan is an illustration of the activities studied, as a grounded research, the research plan becomes the main reference for the process of searching field data and building assumptions about the topic under study. Strauss and Corbin believe that grounded theory research is research that relies on the strategies and creativity of researchers, from which creativity researchers can achieve the expected research objectives [12]. Therefore, by following the rules of the learning plan, researchers try to be participatory in research by entering into the teaching process in the classroom, so researchers directly participate in regulating the course of the learning process, collaboration with teachers is very important, as when researchers agree the learning plan is applied in the classroom, preparing all forms of learning needs such as teaching materials, media, and the most suitable model for learning in order to answer research questions. 


\section{Results and Discussion}

\subsection{Findings}

Social studies learning is carried out in the classroom through movie media as a form of strengthening understanding of harmony. The film depicts the Ancient Minaret of Kudus and the Islamization process in Kudus. The film shows the shape of the building and the values contained in the Minaret. The narrative displayed in the film is broadly shown as follows:

"The Minaret of Mosque is a manifestation of the building resulting from the acculturation between two Hindu-Javanese cultures with Islam. The Hindu-Islamic-Javanese culture itself is reflected in a temple-like building. Whereas Islamic culture is reflected in its use for adhan".

"This reflection of acculturation from the mosque is also reflected in the style of the gate and also in the interior of the mosque which has a pair of ancient arches called twin door (Lawang Kembar in Java). Acculturation itself is a mixture of two or more cultures that do not erase the original culture."

"This aspect of acculturation is part of Sunan Kudus's efforts to spread Islam in the region. Sunan Kudus saw that there were still many Hindus living in the region. Therefore, as a humanist preacher, he uses a cultural approach to preaching. One of them is by maintaining the wisdom of the Hindu-Javanese community, not disturbing, and teaching Islam with love. Until now the Kudus community still maintains the teachings inherited by Sunan Kudus, the most obvious of which is harmony".

After watching an 18-minute movie, students are then prepared to make a summary sourced from films, articles, and books. Articles can be accessed via the internet, students are allowed to open their smartphones. In this process students trace information about cultural acculturation, tolerance and intolerant activities in society. After students carry out this activity, students discuss the results of their work.

The film attracts students' views, enthusiastically students are able to participate in learning activities enthusiastically. They pay attention to the film in full from beginning to end. Until the class atmosphere is quite calm. Movie media is able to provide a better picture of historical narratives. Illustrations and general descriptions of the history of the Ancient Minaret of Kudus are well displayed. Student Number 1 (SN1) argues: "The film is enough to provide an understanding of cultural acculturation in the Kudus Minaret, I see there is respect, mutual respect, even love in the film".

SN2 commented: "Acculturation of culture in the Ancient Minaret is very interesting to learn, the role of Sunan Kudus is very large in the process of acculturation. This can be used as a source of reflection for stabilizing personality". SN4 argues: "Kudus history turned out to be unique, I often went to the Minaret but did not think about what was discussed in the film. In the film it was quite complete and I began to understand the meaning of tolerance. From the smallest things such as respecting and maintaining the feelings of other religious people ".

SN3 argues: "I agree with SN2, the acculturation is very interesting, I can see that the acculturation process of culture in Kudus is unique, like the word SN4, my understanding of tolerance is increasing after learning through film". This is in line with what was conveyed by SN6: "Social studies learning should teach more tolerance, I often see the news and it is not in accordance with my conscience, there are sweeps by hardliners, there is violence of verbalism 
on social media, I was worried initially. After seeing this film I began to understand how to behave about that phenomenon".

SN5 commented critically, that: "Social studies learning this time is quite fun, actually I am waiting for the tolerance issue because lately there are a lot of intolerant activities in the community, as mentioned by SN6, I agree with all the movie statements, I see that it can have an impact great for sustainable harmony in Indonesia. Through our active role, I believe Indonesia remains peaceful". TN1 closes: "This learning is reflex inquiry, giving students knowledge, opening the way for them to find further information in both journals and books. I am very satisfied with today's activity. When students are able to comment positively about harmony and have been able to determine attitudes about intolerance activities, then I have been proud, that today's lesson has succeeded in accordance with the expected goals ".

\subsection{Discussion}

In contrast to the United States, Britain, and countries in Europe, where multiculturalism is generally cultural among nations [13], [14], cultural diversity comes from outside their nation. The multiculturalism in Indonesia is cultural in nature between ethnicities and interfaith who have a long historical background [15]-[17]. Multiculturalism in the context of development is a supporting aspect that can be used as social capital for sustainable harmony in Indonesia [18][20]. In the context of historis, Sunan Kudus through the Ancient Minaret of Kudus has given an example that coexistence is better than war. The side-by-side process of Islam with Hinduism and Javanese culture has given rise to buildings that are so artistic and of high value [10]. It is a local potential that can be used to respond to the current phenomenon related to religious sentiment, intolerance and prejudice between groups.

Galambos [21], Handerson et al. [18], and Avery [22] have proven that social learning with the aim of forming a peaceful multicultural society is very important to do. This can be achieved through the integration of learning with advanced technology [23]-[25]. Bryan and Frances [26], Demircioglu [27] revealed that technology integration can have a positive impact on learning, students can be enthusiastic about the learning delivered. The study also revealed, the cultural impact of computer technology as a supporting system in learning. Research conducted supports these expert opinions. Social studies learning based on the results of the above data collection has been more progressive in responding to the phenomenon in society, namely intolerance. This phenomenon has threatened the integrity of Indonesian society. Therefore, referring to Banks explaining social studies learning as a subject that is most likely to respond to odd phenomena in society [28]. This was proven through this research that, by using movie media, journal articles, and books that can be accessed on the internet, students' tolerance can be strengthened. Students' awareness of the importance of living in harmony has begun to build, even they are able to associate between historical heritage, cultural acculturation, and intolerance phenomena. Through this research it was agreed that acculturation of culture became social capital for more responsive social studies learning, the Ancient Minaret of Kudus as a high historical heritage that acculturated Islamic-Hindu-Javanese culture has been able to provide experience to students about the importance of inter-religious tolerance. 


\section{Conclusion}

This research has revealed the impact of learning through film media which is quite large in building students' imagination about tolerance. It was realized that film is able to provide more inspiration about the value of life, one of which is tolerance. The rise of the phenomenon of intolerance in society is a threat that needs to be responded by social studies education. Social studies learning that is integrated with technology can make students' enthusiasm and tolerance awareness awake. This can reduce the chances of students to act intolerantly in society. Even those with experience gained through learning can become agents for peace. An important recommendation of this research is that social studies learning is integrated with technology, it is better that teachers also need to utilize the potential of historical heritage to build awareness of tolerance. 


\section{References}

[1] W. Wasino, 'Indonesia: from Pluralism to Multiculturalism', Paramita Hist. Stud. J., vol. 23, no. 2, 2013.

[2] T. Kobayashi, 'Bridging social capital in online communities: Heterogeneity and social tolerance of online game players in Japan', Hum. Commun. Res., vol. 36, no. 4, pp. 546-569, 2010.

[3] K. J. Miller and M. M. Sessions, 'Infusing Tolerance, Diversity, and Social Personal Curriculum into Inclusive Social Studies Classes Using Family Portraits and Contextual Teaching and Learning.', Teach. Except. Child. Plus, vol. 1, no. 3, p. n3, 2005.

[4] G. Wan, 'Teaching Diversity and Tolerance in the Classroom: A Thematic Storybook Approach.', Education, vol. 127, no. 1, 2006.

[5] R. Barr, J. L. Barth, and S. S. Shermis, The nature of the social studies. ETC, 1978.

[6] D. L. Martinson, 'Building a Tolerance for Disagreement an Important Goal in Social Studies Instruction', Clear. House J. Educ. Strateg. Issues Ideas, vol. 78, no. 3, pp. 118-122, 2005.

[7] A. Mummendey and M. Wenzel, 'Social discrimination and tolerance in intergroup relations: Reactions to intergroup difference', Personal. Soc. Psychol. Rev., vol. 3, no. 2, pp. 158-174, 1999.

[8] S. Nieto, 'Moving beyond tolerance in multicultural education', Teach. Toler., 1993.

[9] J. A. Banks, Educating Citizens in a Multicultural Society. Multicultural Education Series. ERIC, 1997.

[10] S. Salam, Menara Kudus: the minaret of Kudus. Centre for Islamic Studies and Research, 1989.

[11] H. Kurniawan, 'THE ROLE OF CHINESE IN COMING OF ISLAM TO INDONESIA: TEACHING MATERIALS DEVELOPMENT BASED ON MULTICULTURALISM', Paramita Hist. Stud. J., vol. 27, no. 2, pp. 238-248, 2017.

[12] A. Strauss and J. Corbin, 'Grounded Theory in practice Sage', 1997.

[13] J. W. Ferrar, 'The dimensions of tolerance', Pac. Sociol. Rev., vol. 19, no. 1, pp. 63-81, 1976.

[14] O. Leirvik and R. Kaymakcan, Teaching for tolerance in Muslim majority societies. Centre for Values Education (DEM) Press, 2007.

[15] R. Romadi and G. F. Kurniawan, 'Pembelajaran Sejarah Lokal Berbasis Folklore Untuk Menanamkan Nilai Kearifan Lokal Kepada Siswa', Sej. Dan Budaya J. Sej. Budaya Dan Pengajarannya, vol. 11, no. 1, pp. 79-94, 2017.

[16] P. Suparlan, 'Indonesia Baru Dalam Perspektif Multikulturalisme”', Dalam Hari. Media Indones., vol. 10, 2001.

[17] P. Suparlan, 'Menuju masyarakat Indonesia yang multikultural', Antropol. Indones., 2014.

[18] D. Henderson-King and A. Kaleta, 'Learning about social diversity: The undergraduate experience and intergroup tolerance', J. High. Educ., vol. 71, no. 2, pp. 142-164, 2000.

[19] C. C. Martell and K. M. Stevens, 'Equity-and tolerance-oriented teachers: Approaches to teaching race in the social studies classroom', Theory Res. Soc. Educ., vol. 45, no. 4, pp. 489-516, 2017.

[20] P. Suparlan and H. Sigit, Culture and fertility: the case of Indonesia, vol. 22. Institute of Southeast Asian Studies, 1980.

[21] C. Galambos, 'From the editor: Political tolerance, social work values, and social work education', J. Soc. Work Educ., vol. 45, no. 3, pp. 343-348, 2009.

[22] P. G. Avery, 'Teaching tolerance: what research tells us.(Research and Practice)', Soc. Educ., vol. 66, no. 5, pp. 270-276, 2002.

[23] P. G. Avery, J. L. Sullivan, and S. L. Wood, 'Teaching for tolerance of diverse beliefs', Theory Pract., vol. 36, no. 1, pp. 32-38, 1997.

[24] N. Berggren and T. Nilsson, 'Globalization and the transmission of social values: The case of tolerance', J. Comp. Econ., vol. 43, no. 2, pp. 371-389, 2015.

[25] A. Zakin, 'Hand to hand: Teaching tolerance and social justice one child at a time', Child. Educ., vol. 88, no. 1, pp. 3-13, 2012.

[26] A. Bryan and F. Vavrus, 'The promise and peril of education: the teaching of in/tolerance in an era of globalisation', Glob. Soc. Educ., vol. 3, no. 2, pp. 183-202, 2005.

[27] I. H. Demircioglu, 'Using historical stories to teach tolerance: The experiences of Turkish eighthgrade students', Soc. Stud., vol. 99, no. 3, pp. 105-110, 2008. 
[28] J. A. Banks, Race, culture, and education: The selected works of James A. Banks. Routledge, 2006. 